\title{
PHYTOSOCIOLOGICAL CHARACTERISTIC OF THE PLANT COMMUNITIES WITH THE OCCURRENCE OF ENDEMIC SPECIES CYCLAMEN FATRENSE
}

\author{
Róbert KANKA*, Peter TURIS**, Viktória CHILOVÁ****
}

\begin{abstract}
In this contribution we bring together the basic phytosociological characteristics of communities with the presence of species Cyclamen fatrense in the herb layer. The analysis was made on the basis of 30 original phytosociological relevés. The main criterion for the relevés recording was the selection of the broadest possible range of biotopes with presence and the highest possible abundance of species Cyclamen fatrense on the entire area of its occurrence, which is represented by the Vel'ká Fatra and Starohorské vrchy Mts. The forest phytocoenoses of the association Carici albae-Fagetum Moor 1952, and phytocoenoses of clearings of the association Epilobio-Atropetum bella-donnae R. Tx. 1931 em. 1950, were classified by using Zürich-Montpellier School method. Additionally, 18 relevés with the presence of species Cyclamen fatrense were excerpted from already published works and detailed comparison was also made.

Key words: Cyclamen fatrense, endemic species, phytosociology, Carici albae-Fagetum, Epilobio-Atropetum belladonnae, Vel'ká Fatra Mts, Starohorské vrchy Mts

\section{Izvleček}

V članku so prikazane osnovne fitosociološke značilnosti združb z vrsto Cyclamen fatrense. Analizirali smo jih na podlagi 30 originalnih popisov. Glavno merilo pri izbiri popisnih ploskev je bil izbor čim širšega obsega rastišč s prisotno vrsto Cyclamen fatrense, na celotnem območju njenega pojavljanja, ki ga predstavljata gorovji Vel'ká Fatra in Starohorské vrchy. Rastišča smo izbirali tam, kjer ima vrsta največjo abundanco. S standardno srednjeevropsko metodo smo gozdne združbe uvrstili v asociacijo Carici albae-Fagetum Moor 1952 in združbe posek v asociacijo Epilobio-Atropetum bella-donnae R. Tx. 1931 em. 1950. Dodatno smo zbrali 18 objavljenih popisov z vrsto Cyclamen fatrense in jih vključili v primerjave.

Ključne besede: Cyclamen fatrense, endemična vrsta, fitosociologija, Carici albae-Fagetum, Epilobio-Atropetum belladonnae, gorovje Vel'ká Fatra, gorovje Starohorské vrchy.
\end{abstract}

\section{INTRODUCTION}

Cyclamen fatrense is an important endemic species of the Slovak flora with the small area of occurrence covering parts of the Vel'ká Fatra and Starohorské vrchy Mts. It grows mainly in broadleaf and mixed forests of the montane altitudinal belt. It persists also in several different development stages created by the forest management activities in the past.

Phytosociological analysis of plant communities with the presence of Cyclamen fatrense has not yet been made, and this endemic species has been mentioned only sporadically in botanical and phytosociological literature. The first group of papers includes unspecified limestone beech forests (e.g. Halda \& Soják 1971, Bernátová \& Feráková 1999, Kliment 1999). Suza (1931) furnished evidence of species also in fir and beech-fir forests and their fringes, or in dense spruce monoculture. Phytosociological relevés with the presence of Cyclamen fatrense (named as Cyclamen, Cyclamen europaeum or Cyclamen purpurascens) were published by Klika (1926,

\footnotetext{
* Institute of Landscape Ecology of the Slovak Academy of Sciences, Štefánikova 3, P. O. Box 254, SK-81499 Bratislava, Slovak Republic; e-mail: robert.kanka@savba.sk

** The Low Tatras National Park, Zelená 5, SK-97401 Banská Bystrica, Slovak Republic; e-mail: turis@sopsr.sk *** The Great Fatra National Park, Čachovský rad 7, SK-03861 Vrútky, Slovak Republic; e-mail: chilova@sopsr.sk
} 
1927, 1936, 1949), in works dealing with forest communities of the Vel'ká Fatra Mts. The species was recorded within the frame of two relevés; in beech forest specified as „Fagetum, type Oxalis-Maianthemum", and in spruce forest specified as "Piceetum" (Picetum in original paper, Klika 1926). The next three relevés are from the mixed forests classified as „Piceetum-Fagetum carpaticum typicum" (Klika 1927). The abundance of Cyclamen fatrense in the presented relevés ranges from „r“ to „+“". Klika (1936) included two relevés with the occurrence "+" of $C$. fatrense of the association Fagetum carpaticum Fatrae caricetosum albae. In his last work from Vel'ká Fatra Mts (1949), species C. fatrense is mentioned as significant species (constancy class I) for the association Abieto-FagetoCaricetum albae. In the work of Kurzová-Urválková (1979) Cyclamen fatrense is recorded in 10 relevés of association Carici humilis-Pinetum Klika 1949 mainly with abundance "+", rarely "r".

Hendrych (1981) assumed the origin of the species Cyclamen fatrense Halda et Soják by the process of speciation from Cyclamen purpurascens Mill., which has been spread temporarily also to Slovakia. After worsening of climatic conditions, the original species Cyclamen purpurascens retreated from the territory of Slovakia and the phylogenesis headed towards a new taxon. The conditions and reasons leading to speciation of $C$. fatrense are not well known, however it is possible to take into account mainly climatic, geomorphologic, edaphic or other factors related to the biology of the taxon (e.g. pollinating, dissemination of seeds etc.). It is less relevant to consider the persistence of this taxon in the area of Vel'ká Fatra and Starohorské vrchy Mts, on account of different phytosociological conditions.

The main objective of this contribution is to present the phytosociological and ecological characteristics of plant communities with presence of the endemic species Cyclamen fatrense, in order to compare the described phytosociological units with identical ones from other mountain areas of the Slovak republic, to summarize existing information from published papers, and thus provide a basis for better knowledge of the species and its protection.

\section{METHODS}

Phytosociological relevés were made in compliance with the Zürich-Montpellier School methods (Braun-Blanquet 1964), in which we used mainly the methodical works of Moravec et al. (1994) and Kent \& Coker (1994). The representative stands of the particular community were chosen in such a way as to record the highest possible variability of the community with respect to the homogeneity of the relevé area. The abundance was estimated by the new Braun-Blanquet scale for abundance and dominance (Barkmann et al. 1964).

Summarily, 30 relevés were made in the Vel'ká Fatra and Starohorské vrchy Mts, which represents the entire area of the Cyclamen fatrense occurrence. The data obtained from the field were stored in the database TURBOVEG (Hennekens \& Schaminee 2001). The basic arrangement of the phytosociological table and tabular synthesis was made with the JUICE 6.2 software (Tichý 2002). The same software was also used for the calculation of Ellenberg's indicator values. The methodical approach proposed by (Jurko 1990) was followed and Ellenberg indicator values were calculated as mean weighted values for each relevé. Relevés are lined up in the phytosociological tables on the basis of decreasing constancy.

The nomenclature of the vascular plants is according to Marhold et al. (1998), and of the bryophytes after the work of Kubinská \& Janovicová (1998). Phytosociological units are in compliance with syntaxonomic nomenclature of the vegetation of Slovakia (Mucina \& Maglocký 1985) and Jarolímek et al. (1997).

For the purpose of finding and visualizing mutual relations among the determined syntaxa the indirect gradient analysis and the model DCA - detrended correspondence analysis (Hill \& Gauch1980) was chosen. The software CANOCO (ter Braak \& Šmilauer 2002) was used for the calculation of this model.

\section{RESULTS}

Cyclamen fatrense as a species with a preference for semi-shadow and shadow light conditions in two basic types of biotope was recorded - in forest stands and glades. Its occurrence is primary in forest phytocenoses: in clearings and glades it is able to persist generally with the lower abundances over some period until formation of the new forest stand. Classification of the relevés into syntaxonomic units was based on works dealing with the phytosociology of submontane and montane limestone beech forests and glades. After analysis, the forest phytocoenoses were classified to the association Carici albae-Fagetum Moor 1952; glades to association Epilobio-Atropetum bella-donnae R. Tx. 1931 em. 1950. 
Analytical tables of the mentioned association have been published by Fajmonová (1972, 1973, 1978), Fajmonová \& Šimeková (1973), Šimeková (1974), Miadok (1979), Jurko \& Kubíček (1974) and Jurko \& Kontriš (1982) from various mountains in Slovakia. The heterogeneity of the presented association is documented by the relatively high number of subassociations, variants and subvariants in these works. Fajmonová $(1981,1986)$ studied glade phytocoenoses of the Atropion alliance, mainly in the beech forest altitudinal zone. The final description and characteristics of the association respects the results of Jarolímek et al. (1997).

\section{Description of the plant communities with Cycla- men fatrense}

A. Forest stands (Table 1)

Class: Querco-Fagetea Br.-Bl. et Vlieger in Vlieger 1937

Order: Fagetalia Pawłowski in Pawłowski et al. 1928

Alliance: Fagion Luquet 1926

Suballiance: Cephalanthero-Fagenion R. Tx. in R. Tx. et Oberd. 1958.

Association: Carici albae-Fagetum Moor 1952

Subassociation: typicum Fajmonová et Šimeková 1973

The evaluated forest phytocoenoses with presence of the species Cyclamen fatrense were classified into the association Carici albae-Fagetum, which represents the limestone beech forests of the submontane and montane belt. Relevés were made in forest stands at altitudes of $470-985 \mathrm{~m}$ a. s. 1 . in the beech and fir-beech forest altitudinal zone (sensu Zlatník 1959), and in the submontane (reaching marginally also to the upland) altitudinal zone on various stand expositions (range betwen $\mathrm{SE}$ and $\mathrm{NE}$ ) with slopes of $15^{\circ}-45^{\circ}$. The bedrock is formed by dolomites and limestones; the soil is modal rendzina.

Fagus sylvatica is dominant in three layer (abundance $40 \%-95 \%$, on average $80 \%$ ), accompanied mostly by cultivated species Picea abies, which in some stands is subdominant or also dominant. The presence of species Acer pseudoplatanus is characteristic for scree habitats; Abies alba, Larix decidua and Sorbus aria agg. occur sporadically in several relevés. The shrub layer (abundance 1\%-20\%, average $7.5 \%$ ) is a compound of few species, Fagus sylvatica is prevalent here. The herb layer (abundance $5 \%-98 \%$, average $47 \%$ ) is species rich, and the abundances markedly vary depending on the thickness of the litter on the soil surface. Constant and abundant species Hieracium murorum, Mercurialis perennis and Prenanthes purpurea, as well as the seedlings of Acer pseudoplatanus and Fagus sylvatica, comprise significant part of the herb layer. Bryophytes were determined in all relevés in which they occurred. The highest presences are those of Dicranum scoparium and Hypnum cupressiforme. The association Carici albae-Fagetum is a relatively heterogeneous syntaxon and therefore it is necessary to divide it into the lower syntaxonomical units. All classified phytocoenoses represent a mutually intersected mosaic of herbaceous and grassy limestone beech forests.

According to the NATURA 2000 scheme, the described forest stands are included in biotope of European importance 9150: Medio-European limestone beech forests.

\section{Lower syntaxa:}

a) typical variant

The phytocoenoses of a type rich in grasses, opposite the stands of the herbaceous type (included in variant inops Carex alba) occupy soils with a high content of carbonates in fine-grained proportion (Fajmonová 1973). The herb layer is composed mainly of Carex alba and Calamagrostis varia, which together with Cirsium erisithales, Daphne mezereum, Fragaria vesca, Hieracium murorum, Lilium martagon, Senecio ovatus and Valeriana tripteris differentiate the typical variant. The variant is can divided into the two subvariants:

\section{aa) typical subvariant}

The subvariant includes phytocoenoses of the more gentle slopes and its occurrence is bound to less extreme habitat conditions. It is differentiated by the species Dentaria bulbifera and Polygonatum verticillatum.

ab) subvariant with Pinus sylvestris

It includes the phytocoenoses of more extreme habitats, mostly steeper under-ridge slopes and small edges. The group of differential species is relatively large: Pinus sylvestris $\left(\mathrm{E}_{3}\right)$, Anthericum ramosum, Berberis vulgaris, Cruciata glabra, Galium album, Melica nutans, Pimpinella major, Sesleria albicans, Tithymalus cyparissias, Viburnum lantana and Vincetoxicum hirundinaria.

\section{b) variant inops}

To the variant belong the phytocoenoses, in which the taxon Carex alba was not recorded. Fajmonová (1973) characterized the mentioned phytocoenoses as a herbaceous type occurring mostly on clay limestones with an amount of skeleton in the 
soil profile due to weathering of the bedrock. The main consequence is a slight increase of total acidity in upper soil horizons. The weaker aeration and lower mellowness are also characteristic for the soil conditions, which ecologically reflect on the species composition. There ia an absence of species Carex alba and Calamagrostis varia, which, together with species Cirsium erisithales, Daphne mezereum, Fragaria vesca, Hieracium murorum, Lilium martagon, Senecio ovatus and Valeriana tripteris, negatively differentiate the variant. Variant inops is considerably poorer in terms of the species richness (relevé nr. 25 represents a smooth transition to association Dentario bulbiferae-Fagetum (Zlatník 1935) Hartmann 1953), the species Hedera helix and Pulmonaria officinalis are differential within the frame of subassociation. Fajmonová (1973) designated these specific, poor phytocoenoses as the Hedera helix-nudum type.

\section{B. Stands of clearings (Table 2)}

Class: Epilobietea angustifolii R. Tx. et Preising R. Tx. ex von Rochow 1951

Alliance: Atropion Br.- Bl. ex Aichinger 1933

The alliance represents the first development stage of glades after cutting of forest communities of the alliances Fagion Luquet 1926 and Carpinion Issler 1931 on the nutritive substrates. It is optimally developed on base-rich soils, at altitudes up to $1000 \mathrm{~m}$ a. s. 1. The spectrum of life forms is typified by the prevalence of hemicryptophytes.

\section{Association: Epilobio-Atropetum bella-donnae R. Tx. $1931 \mathrm{em} .1950$}

The described glade phytocoenoses with the presence of Cyclamen fatrense species occur in the beech and fir-beech forest altitudinal zone $(650-995 \mathrm{~m}$ a. s. 1.), slope gradient ranges from $15 \%$ to $20 \%$, exposition ranges between WSW and NE. The species abundance declines by more than half of that in the forest stands as a consequence of increased light radiation. The geological bedrock is formed by dolomites and limestones; soil is modal rendzina. These heliophilous and nitrophilous short-living communities, whose formation was caused by the change of habitat conditions after removal of forest, represent various development stages of succession towards forest. As they are labile and quickly developed, their exact floristic delimitation has been difficult (Oberdorfer 1973, 1978).

The shrub layer $(2 \%-70 \%)$ was developed in three relevés. It comprises the species Acer pseudoplatanus, Fagus sylvatica, Larix decidua, Picea abies, Pinus sylvestris and Rosa canina agg. In the herb layer
(60\%-100 \%) co-occur the typical glade species: Atropa bella-donna, Cirsium arvense, Eupatorium cannabinum and constant species of the community Carici albae-Fagetum:Acer pseudoplatanus, Calamagrostis varia, Carex alba, Cyclamen fatrense and Fragaria vesca. The bryophyte layer was recorded with small abundances $(2 \%-5 \%)$ in two relevés.

\section{Evaluation of Ellenberg's indicator values}

The values for light, temperature, continentality, moisture, reaction and nutrients were calculated on the basis of the methodical approach of Ellenberg (1974) and Ellenberg et al. (1992). Software JUICE 6.2 (Tichý 2002) was used for this analysis, $91 \%$ of all species included in the relevés corresponded to Ellenberg's indicator values in the database. The calculation was done for each particular relevé,

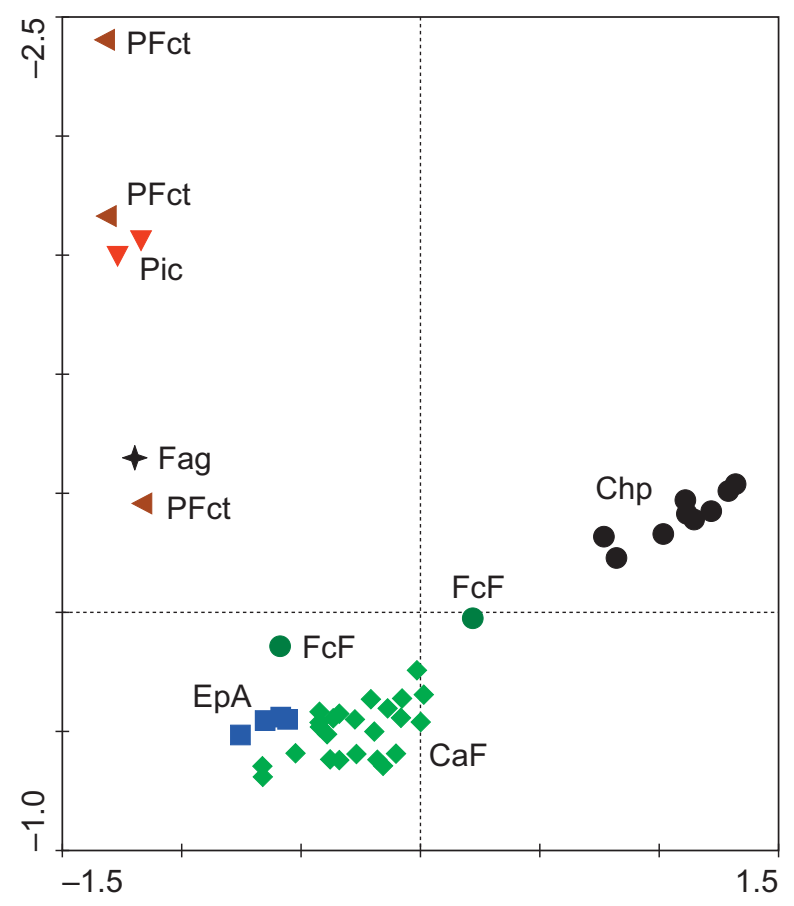

Figure 1: All recognised syntaxa with presence of the Cyclamen fatrense. Detrended correspondence analysis, each point represents one relevé. CaF - Carici albae-Fagetum, EpA - Epilobio-Atropetum belladonnae, FcF - Fagetum carpaticum Fatrae caricetosum albae, ChP - Carici humilis-Pinetum, PFct - Piceetum-Fagetum carpaticum typicum, Pic - Piceetum, Fag - Fagetum.

Slika 1: Analiza DCA, vsaka točka predstavlja popis. CaF Carici albae-Fagetum, EpA - Epilobio-Atropetum belladonnae, FcF - Fagetum carpaticum Fatrae caricetosum albae, ChP - Carici humilis-Pinetum, PFct - Piceetum-Fagetum carpaticum typicum, Pic - Piceetum, Fag - Fagetum. 
summarily 48 relevés: Carici albae-Fagetum - 26, Epilobio-Atropetum bella-donnae - 4, Klika (1926) - 3, Klika (1927) - 3, Klika (1936) - 2, Kurzová-Urválková (1979) - 10. Analysis showed relatively significant differences between particular syntaxa. Stands of association Carici albae-Fagetum, where Cyclamen fatrense survives with the highest abundances are characterized by the half shade, weak warm and sub-oceanic conditions; soils are fresh, weak acid - weak alkaline and moderate for soil nutrients. The range of calculated values for all considered syntaxa is large (Tab. 3, 4, Fig. 1). The largest amplitude is observed in relation to the values of light (shadowhalf shadow - half light), soil moisture (dry-fresh - fresh-moist) and soil nutrients (poor soils - soils rich in nutrients). It is possible to state that the $C y$ clamen fatrense persists with lower abundances in relatively broad spectrum of ecological conditions.

Table 3: Range of Ellenberg's indicator values calculated for particular relevés.

Tabela 3: Razpon Ellenbergovih indikacijskih vrednosti, izračunanih za posamezni popis.

\begin{tabular}{lclcl}
\hline & Lowest & Descriptive characteristic & Highest & Descriptive characteristic \\
\hline Light & 3.6 & Shadow-half shadow & 6.6 & Half light \\
Temperature & 4.4 & Cool-intermediate & 5.3 & Intermediate \\
Continentality & 3.4 & Oceanic-suboceanic & 4.4 & Suboceanic \\
Moisture & 3.8 & Dry-fresh & 5.6 & Fresh-moist \\
Soil reaction & 5.8 & Weakly acid-neutral & 7.5 & Neutral-basic \\
Nutrients & 2.9 & Poor & 5.9 & Rich \\
\hline
\end{tabular}

Table 4: Average numbers of Ellenberg's indicator values for particular syntaxa

Tabela 4: Povprečje Ellenbergovih indikacijskih vrednosti za posamezni sintakson.

\begin{tabular}{lccccccc}
\hline & All & Forests & Glades & Klika (1926) & Klika (1927) & Klika (1936) & Kurz.-Urv. (1979) \\
\hline Light & 5.16 & 4.83 & 5.65 & 5.27 & 4.4 & 4.90 & 6.36 \\
Temperature & 4.83 & 4.83 & 4.95 & 4.90 & 4.63 & 5.05 & 4.75 \\
Continentality & 3.87 & 3.73 & 3.93 & 3.77 & 3.93 & 3.95 & 4.22 \\
Moisture & 4.80 & 4.92 & 4.90 & 5.23 & 5.23 & 4.90 & 4.18 \\
Soil reaction & 6.83 & 6.79 & 6.75 & 6.23 & 6.13 & 7.05 & 7.33 \\
Nutrients & 4.56 & 4.79 & 5.13 & 5.33 & 5.30 & 4.95 & 3.22 \\
\hline
\end{tabular}

\section{Indirect gradient analysis}

Detrended correspondence analysis (Fig. 2) confirmed the assumed differences among particular syntaxa. Stands of both associations Carici albaeFagetum and Epilobio-Atropetum bella-donnae, where the species Cyclamen fatrense occurs with the highest abundances, are unambiguously ecologically defined. On the other hand, comparison of the association Carici albae-Fagetum within the frame of the

Figure 2: Association Carici albae-Fagetum, 185 selected relevés from already published articles, 26 relevés with presence of the Cyclamen fatrense. Detrended correspondence analysis, each point represents one relevé.

Slika 2: Asociacija Carici albae-Fagetum, 185 izbranih popisov iz objavljenih člankov, 26 popisov s prisotno Cyclamen fatrense. Analiza DCA, vsaka točka predstavlja popis.

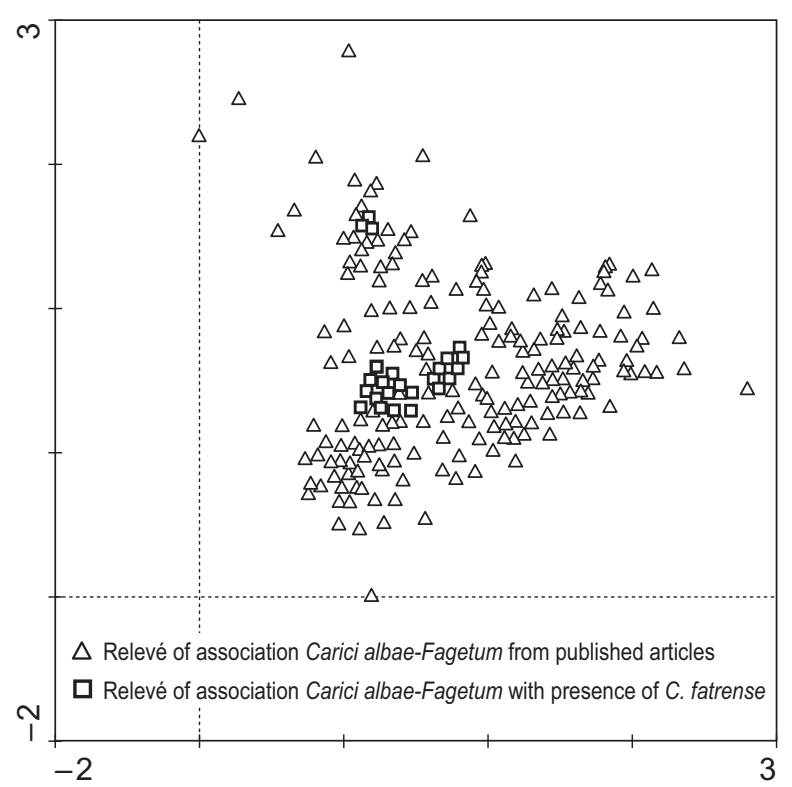


whole area of Slovakia has not shown any important and clear differences. The comparison was done on the basis of works by Fajmonová \& Šimeková (1973), Šimeková (1974), Fajmonová (1978), Jurko \& Kontriš (1982), Jurko \& Kubíček (1974), Miadok (1979). Summarily, 185 relevés were analyzed, and the results are presented in Fig. 3.

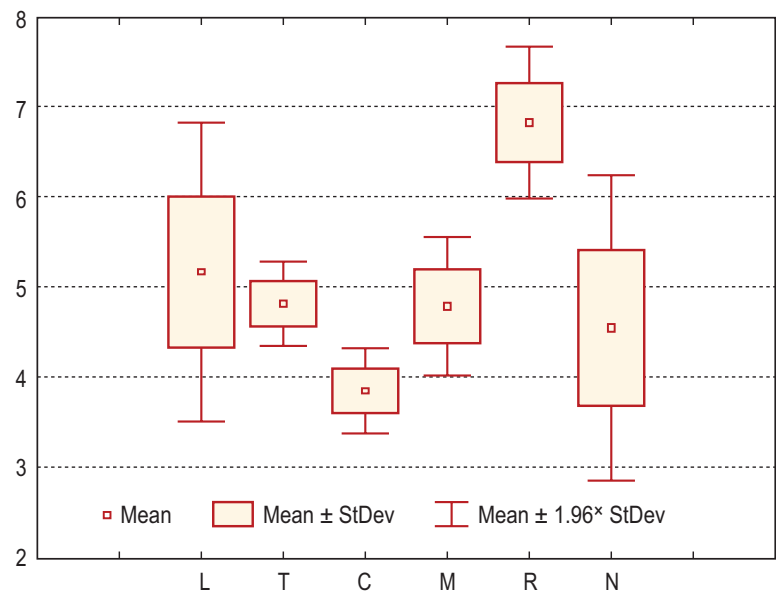

Figure 3: Box and whisker plot of Ellenberg's indicator values. All 48 relevés are included. L - light, T - temperature, $\mathrm{C}$ - continentality, $\mathrm{M}$ - moisture, $\mathrm{R}$ - soil reaction, $\mathrm{N}$ - soil nutrients.

Slika 3: Okvir z ročaji Ellenbergovih indikacijskih vrednosti. Vključenih je vseh 48 popisov. L - svetloba, T - temperatura, $\mathrm{C}$ - celinskost, $\mathrm{M}$ - vlažnost, $\mathrm{R}$ - reakcija tal, $\mathrm{N}$ - hranila.

\section{DISCUSSION}

The knowledge obtained of the ecological requirements of the taxon and of the appropriate biotopes necessary for its successful occurrence and living might contribute to conservation of this unique endemic taxon. The primary effort, aimed at describing as much as possible of the biotopes with the presence of species Cyclamen fatrense, resulted in one forest and glade association. Association Carici albae-Fagetum is a very heterogeneous syntaxon, which includes several lower syntaxonomic units - subassocations, variants and subvariants which reflect on the relatively high variability of habitat conditions. Stands of clearings also offer appropriate conditions for occurrence of this rare species, although with lower abundance than in forests.

Overall, it is interesting, that although there are various species compositions in the tree layer, species Cyclamen fatrense prefer primarily the phytocoenoses of only one association, Carici albae-Fage- tum. To summarize: the phytosociological centre of occurrence of the endemic species Cyclamen fatrense can be considered to be the phytocoenoses of the association Carici albae-Fagetum, where the highest abundances have been reached ("1" and "2" of the Braun-Blanquet scale).

Klika $(1936,1949)$ recorded C. fatrense in old synonyms of this association, namely Fagetum carpaticum Fatrae caricetosum albae and Abieto-Fagetocaricetum albae with lower abundance "+". After deforestation, the species persists also in glade phytocoenoses of the association Epilobio-Atropetum bella-donnae ("+" and "1"). Marginally it was recognized in associations Carici humilis-Pinetum, Piceetum, Fagetum and Piceetum-Fagetum carpaticum typicum ("+" and "r"). Comparison between the association Carici albae-Fagetum with the presence of Cyclamen fatrense, and fundamental works dealing with this syntaxon from the area of Slovakia, did not prove differences in phytosociological character. It is necessary to note that fuller analysis of limestone beech forests is not a purpose of our article, thus the comparison was done in simplified manner. This confirms the theory of Hendrych (1981), who considered climatic, geomorphologic, edaphic or other factors relative to the biology of taxon as being essential.

\section{ACKNOWLEDGEMENTS}

For the determination of bryophytes we thank RNDr. A. Kubinská, CSc., and for help with the determination of some vascular plants we are grateful to Mgr. J. Kollár, PhD. The contribution was prepared within the grant project of the Ministry of Education of the Slovak Republic and the Slovak Academy of Sciences No. 2/6081/26.

\section{REFERENCES}

Barkman, J. J., Doing, H. \& Segal, S. 1964: Kritische Bemerkungen und Vorschläge zur quantitativen Vegetationanalyse. Acta Botanica Neerlandica, Amsterdam, 13: 394-419.

Bernátová, D. \& Feráková, V. 1999: Cyclamen fatrense Halda et Soják. In: Čeřovský, J., Feráková, V., Holub, J., Maglocký, Š. \& Procházka, F.: Červená kniha ohrozených a vzácnych druhov rastlín a živočíchov SR a ČR. Vol. 5. Vyššie rastliny. Príroda, Bratislava, p. 121.

Braun-Blanquet, J. 1964: Pflanzensoziologie. Grund- 
züge der Vegetationskunde. Edition 3. Springer, Wien, New York, 865 pp.

Ellenberg, H. 1974: Zeigenwerte der Gefässpflanzen Mitteleuropas. Scripta Geobotanica, 9, Göttingen, $97 \mathrm{pp}$.

Ellenberg, G, H., Weber, H. E., Düll, R., Wirth, W., Werner, W. \& Paulissen,

D. 1992: Zeigenwerte von Pflanzen in Mitteleuropa. Edition 2. Scripta Geobotanica, 18, Göttingen, 258 pp.

Fajmonová, E. 1972: Príspevok k fytocenológii vápencových bučín Stredného Považia [Carici albae-(Abieti-)Fagetum Klika (1936) 1949]. Biológia (Bratislava), 27: 31-42.

Fajmonová, E. 1973: Prehlad sutinových lesov Stredného Považia. Biológia (Bratislava), 28: 547-561.

Fajmonová, E. 1978: Waldgesellschaften der Strážov - Berggruppe (Nordteil des Gebirges Strážovská hornatina). Acta Facultatis Rerum Naturalis Universitas Comeniae, Botanica, 26, Bratislava, p. 87-105.

Fajmonová, E. 1981: Rúbaniskové spoločenstvá v Javorníkoch. Biológia (Bratislava), 36: 289-295.

Fajmonová, E. 1986: K fytocenológii trávnatých rúbaniskových spoločenstiev v niektorých oblastiach Slovenska. Biológia (Bratislava), 41: 13-20.

Fajmonová, E. \& Šimeková, J. 1973: Beitrag zur Phytosociologischen Klassifikation der Kalkstein Buchenwälder in den Westkarpaten. Acta Facultatis Rerum Naturalis Universitas Comeniae, Botanica, 21: 31-52.

Halda, J. \& Soják, J. 1971: Cyclamen fatrense sp. n., nový druh západokarpatské květeny. Časopis Národního Musea, Oddělení Přírodovědné, Praha, 140, 1/2: 63-65.

Hendrych, R. 1981: Bemerkungen zum Endemismus in der Flora der Tschechoslowakei. Preslia, 53: $97-120$.

Hennekens, S. M. \& Schaminée, J. H. J. 2001: Turboveg, a comprehensive database management system for vegetation data. Journal of Vegetation Science 12: 589-591.

Hill, M. O. \& Gauch, H. G. 1980: Detrended correspondence analysis: An improved ordination technique. Plant Ecology 42 (1-3): 47-58. (DOI 10.1007/BF00048870)

Jarolímek, I., Zaliberová, M., Mucina, L. \& Mochnacký, S. 1997: Rastlinné spoločenstvá Slovenska. 2. Synantropná vegetácia. Veda, Bratislava, 420 pp.

Jurko, A. 1990: Ekologické a socioekonomické hodnotenie vegetácie. Príroda, Bratislava, 200 pp.
Jurko, A. \& Kontriš, J. 1982: Vápencové bučiny Malých Karpát. Biológia (Bratislava), 37: 487493.

Jurko, A. \& Kubíček, F. 1974. Bučiny v centrálnej časti Kremnických vrchov. Biológia (Bratislava), 29: 13-19.

Kent, M. \& Coker, O. 1994: Vegetation description and analysis - a practical approach. John Wiley \& Sons, Chichester, England, 340 pp.

Klika, J. 1926: Poznámky ke geobotanickému výzkumu Vel'ké Fatry. Sborník Přírodovědecké společnosti v Moravské Ostravě, 3: 38-85.

Klika, J. 1927: Příspěvek ke geobotanickému výzkumu Vel'ké Fatry. Preslia, Praha, 5: 6-35.

Klika, J., 1936: Das Klimax-Gebiet der Buchenwiilder in den Westkarpathen. Beihefte zum Botanischen Centralblatt, Dresden, 55/B: 373-418.

Klika, J., 1949: Lesy Vel'ké Fatry. Prírodovedný sborník (Turčiansky Sv. Martin), 4: 7-36.

Kliment, J. 1999: Komentovaný prehl’ad vyšších rastlín flóry Slovenska, uvádzaných v literatúre ako endemické taxóny. Bulletin Slovenskej Botanickej Spoločnosti, Bratislava, 21, Supplement 4, Slovenská botanická spoločnost pri SAV, Botanická záhrada UK, 434 pp.

Kubinská, A. \& Janovicová, K. 1998: Machorasty Bryophytes, 297-331 pp. In: Marhold, K. \& Hindák, F. (eds), Zoznam nižších a vyšších rastlín Slovenska, Veda, Bratislava.

Kurzová-Urválková, O. 1979: Asociácia Carici humilis-Pinetum Klika 1949 v západnej časti Velkkej Fatry. Kmetianum, Martin, 5: 135-151.

Marhold, K., Goliašová, K., Hegedüšová, Z., Hodálová, I., Jurkovičová, V., Kmetová, E., Letz, R., Michalková, E., Mráz, P., Peniašteková, M., Šípošová, H. \& Ťavoda, O. 1998: Paprad’orasty a semenné rastliny - Ferns and Flowering Plants. In: Marhold, K. \& Hindák, F. (eds), Zoznam nižších a vyšších rastlín Slovenska, Veda, Bratislava 333-687 pp.

Miadok, D. 1979: Kalkbuchenwälder im Karstgebiet von Tisovec. Acta Facultatis Rerum Naturalis Universitas Comeniae, Botanica, 27: 77-85.

Moravec, J., Blažková, D., Husová, M., Kolbek, J., Krahulec, F., Neuhäusl, R., Neuhäuslová-Novotná, Z., Hejný, S., Kropáč, Z., Jeník, J., Květ, J., Samek, V., Krečmer, V., Rybníček, K., Rybníčková, E. \& Štěpán, J. 1994: Fytocenologie. Academia, Praha, 404 pp.

Mucina, L. \& Maglocký, Š. (eds) 1985: A list of vegetation units of Slovakia. Documents Phytosociologiques, Camerino, 9: 175-220.

Oberdorfer, E. 1973: Die Gliederung der Epilobietea 
angustifolii-Gesellschaften am Beispiel süddeutscherVegetationsaufnahmen. Acta Botanica Academiae Scientiarum Hungaricae, 19: 235-253.

Oberdorfer, E. 1978: Süddeutsche Pflanzengesellschaften. Teil 2. Gustav Fischer, Stuttgart, 355 pp.

Suza, J. 1931: Poznámky k rozšîření bramboříku (Cyclamen europaeum L.) ve Vel'ké Fatre (Slovensko). Věda Př́rodní, 12: 153-154.

Šimeková, J. 1974: Vápencové bučiny Slovenského raja. Biológia (Bratislava), 29: 263-280.

ter Braak, J. F. C. \& Šmilauer, P. 2002: CANOCO
Reference Manual and CanoDraw for Windows User's Guide to Canoco for Windows: Software for Canonical Community Ordination (version 4.5). Microcomputer Power (Ithaca, NY, USA), Ithaca, NY, USA, 500 pp.

Tichý, L. 2002: JUICE, software for vegetation classification. Journal of Vegetation Science 13: 451-453.

Zlatník, A. 1959: Přehled slovenských lesů podle skupin lesních typů. Vědecké laboratoře biogeocenologie a typologie lesa, LF-VŠZ Brno, č. 3, $178 \mathrm{pp}$.

Recieved 9. 5. 2006

Revision recieved 29. 8. 2006

Accepted 16. 4. 2008

Table 1: Association Carici albae-Fagetum, phytosociological table, V.w. C.a. - variant without Carex alba. Csv - constancy of subvariant, $\mathrm{Cv}$ - constancy of variant, $\mathrm{Ct}$ - total constancy, $\mathrm{Pv}$ - presence of subvariant.

Tabela 1: Asociacija Carici albae-Fagetum, fitocenološka tabela, V.w. C.a. - varianta brez vrste Carex alba. Csv - stalnost subvariante, $\mathrm{Cv}$ - stalnost variante, $\mathrm{Ct}$ - skupna stalnost, $\mathrm{Pv}$ - prisotnost subvariante.

Number of relevé

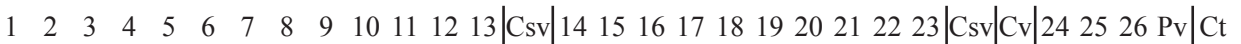
Subassociation typicum

Typical variant

$\mathbf{E}_{3}$

Fagus sylvatica

Picea abies

Acer pseudoplatanus

Abies alba

Larix decidua

Sorbus aria agg.

Ulmus glabra

$\mathbf{E}_{2}$

Fagus sylvatica

Picea abies

Abies alba

Acer pseudoplatanus

Sorbus aria agg.

Differential species of variant without Carex alba

Hedera helix

Pulmonaria officinalis

Differential species of typical variant

Carex alba

Calamagrostis varia

Daphne mezereum

Lilium martagon

Valeriana tripteris

Cirsium erisithales

Hieracium murorum

Senecio ovatus

Fragaria vesca

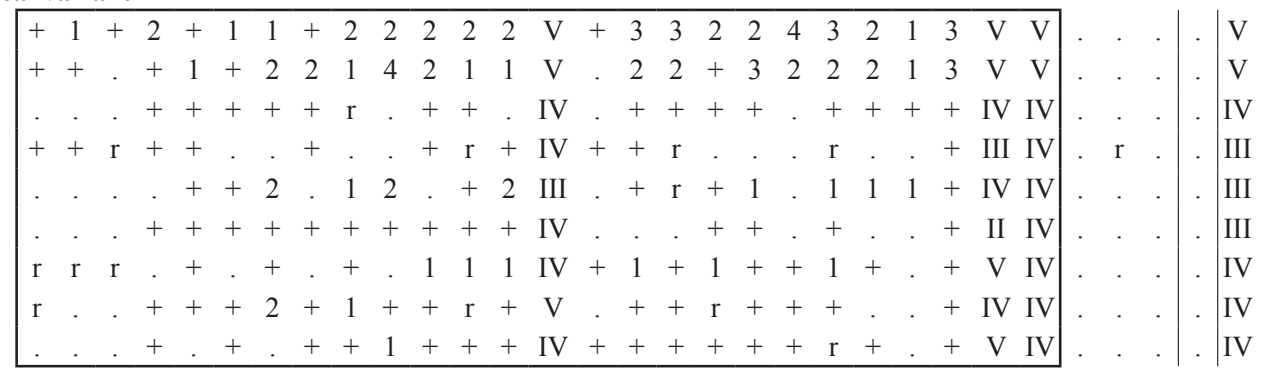


Number of relevé

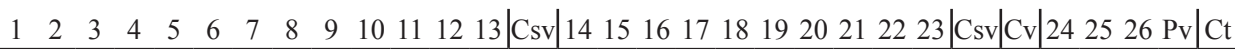

Differential species of typical subvariant

Dentaria bulbifera

Polygonatum verticillatum

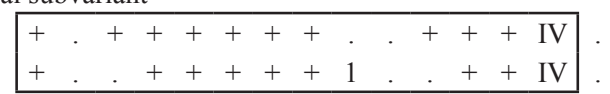

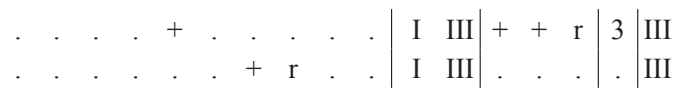

Differential species of subvariant with Pinus sylvestris

Pinus sylvestris $\left(\mathrm{E}_{3}\right)$

Viburnum lantana

Melica nutans

Pimpinella major

Vincetoxicum hirundinaria

Anthericum ramosum

Galium album s.str.

Berberis vulgaris

Cruciata glabra

Tithymalus cyparissias

Sesleria albicans

\section{Other species in $\mathbf{E}_{\mathbf{1}}$}

Cyclamen fatrense

Acer pseudoplatanus

Fagus sylvatica

Epipactis helleborine agg.

Mercurialis perennis

Prenanthes purpurea

Abies alba

Campanula rapunculoides

Mycelis muralis

Sorbus aria agg.

Sorbus aucuparia

Viola reichenbachiana

Ajuga genevensis

Tithymalus amygdaloides

Asarum europaeum

Astrantia major

Melittis melissophyllum

Viola riviniana

Campanula trachelium

Convallaria majalis

Galium schultesii

Orthilia secunda

Picea abies

Corylus avellana

Lathyrus vernus

Carex digitata

Maianthemum bifolium

Rosa pendulina

Rubus saxatilis

Fraxinus excelsior

Heracleum sphondylium

Ranunculus nemorosus

Monotropa hypophegea

Platanthera bifolia

Salvia glutinosa

Solidago virgaurea

Campanula rotundifolia agg.

Carduus glaucinus

Gentiana asclepiadea

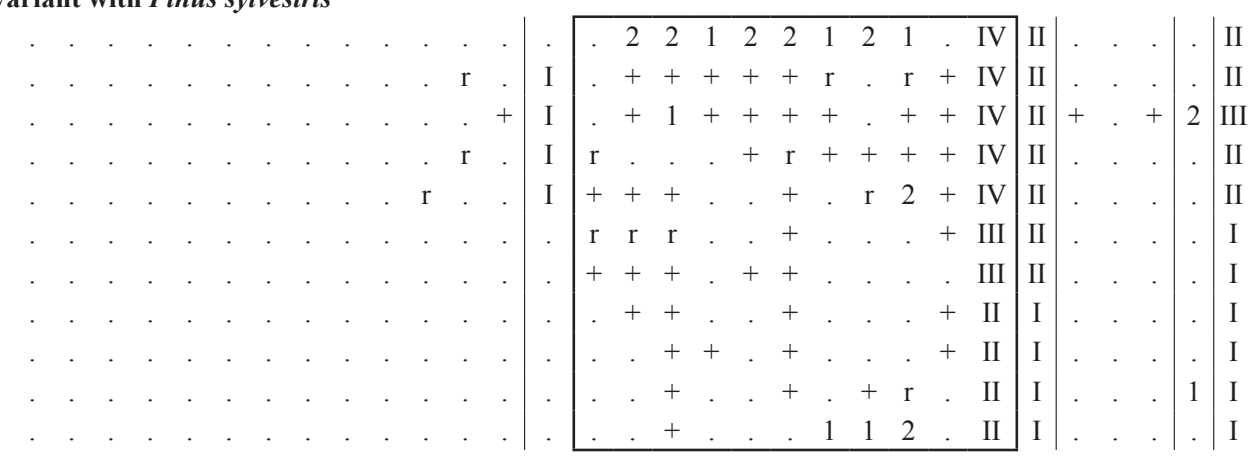

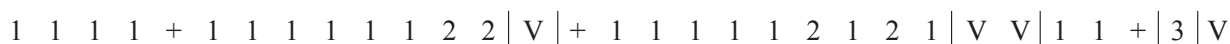

$+++.++++1+1+1 / \mathrm{V}++1+++++1+\mathrm{V} \mathrm{V}+. \quad \mathrm{r} 2 \mathrm{~V}$

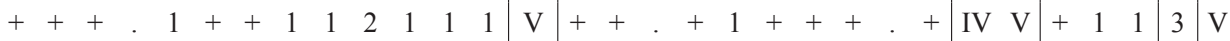

$++\mathrm{r}+++++\mathrm{r} .++\mathrm{V}+\mathrm{r} .+\mathrm{r}+++++\mathrm{V} \mathrm{V} .++2 \mathrm{~V}$

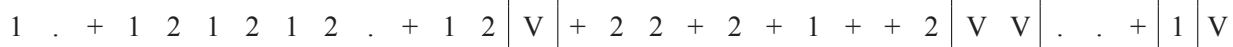

$+.+12++111+11 \mathrm{~V}++++1.1+.11 \mathrm{IV} \mathrm{V}+.+2 \mathrm{~V}$

$+\mathrm{r} r .+++. \mathrm{r} .+\mathrm{r} . \operatorname{IV} \mathrm{r} . \quad+\mathrm{r}++.++$ IV IV $\mathrm{r} . \quad . \quad 11 \mathrm{IV}$

$+. \quad++.++.++$. + III $++++++.+.++\operatorname{IV~IV~} . \quad . \quad+1$ IV

..$++++++1 .+++$ IV $+++++\mathrm{r} . \quad . \quad . \quad \mathrm{r}$ III IV $+. \quad . \quad 1$ IV

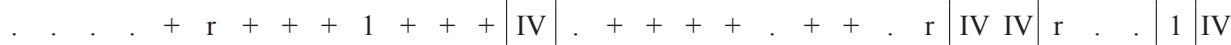

$. \quad .+.+++++++\operatorname{IV} \mathrm{r}++.+\mathrm{r}++$. . + IV IV . . . . III

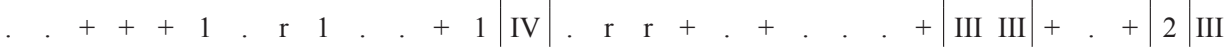

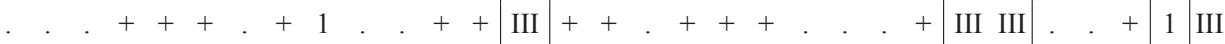

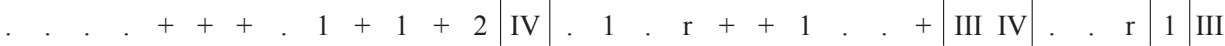

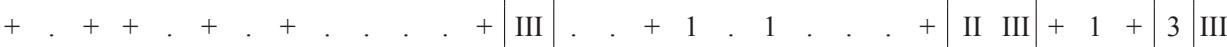

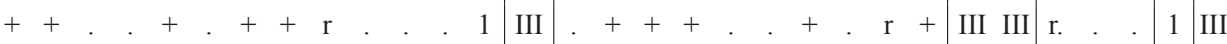

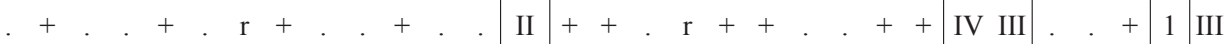

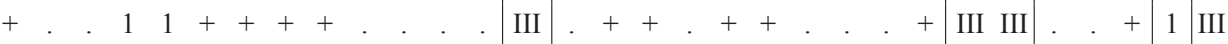

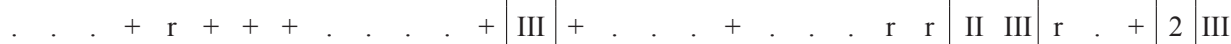

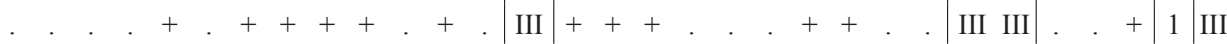

. . . . $2+. .+.+$ II . . $++++11++$ IV III . . + 1 III

. . . +++ . $\mathrm{r} . .++$ III ..++++++ . . + III III . . . . . III

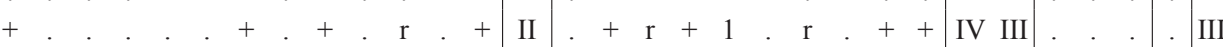

. $\mathrm{r} r$. . . . . . . $\mathrm{r}$ II . . . $\mathrm{r} r+\mathrm{r} .++$ III II 2 r $\mathrm{r} 2$ III

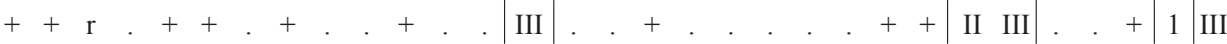

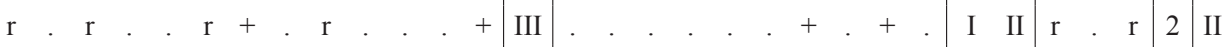

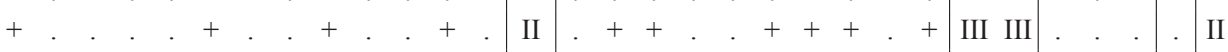

$+. . \quad+.++++$. . . + III . . ...+++++ . $\mathrm{II}$ III . . . .. II

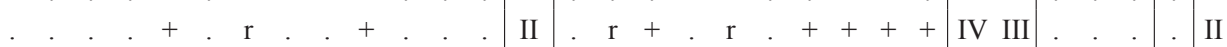

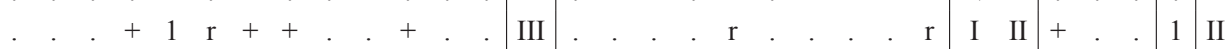

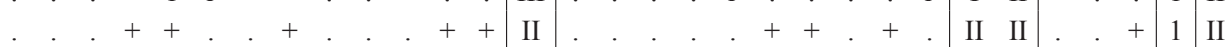

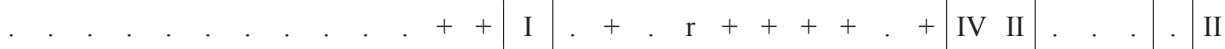

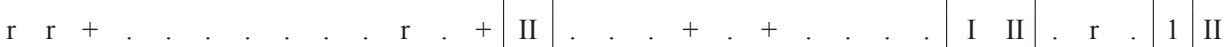

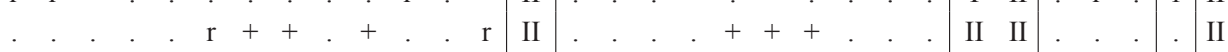

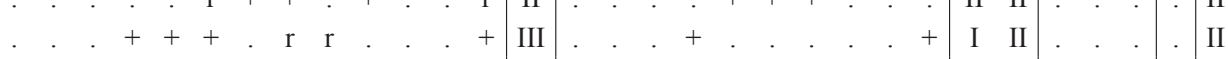

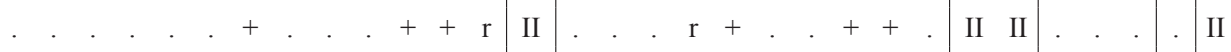

\begin{tabular}{lc|c|ccccccccc|cc|ccc|c|c}
+ & $\mathrm{r}$ & $\mathrm{II}$ \\
+ & + & $\mathrm{I}$ & $\cdot$ & $\cdot$ & $\cdot$ & $\mathrm{r}$ & + & $\cdot$ & $\cdot$ & + & + & $\cdot$ & $\mathrm{II}$ & $\mathrm{II}$ \\
$\cdot$ & + & + & $\cdot$ & $\cdot$ & + & $\cdot$ & $\cdot$ & + & + & $\mathrm{III}$ & $\mathrm{II}$ & $\cdot$ & $\cdot$ & $\cdot$ & $\cdot$ & $\mathrm{II}$ \\
$\cdot$ & $\mathrm{II}$
\end{tabular}

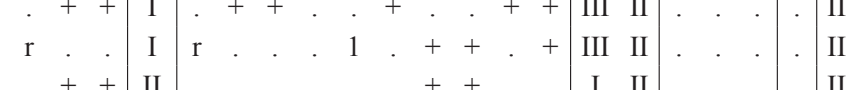


Number of relevé \begin{tabular}{lllllllllllll|l|l|lllllllll|l|l|llll|l}
1 & 2 & 3 & 4 & 5 & 6 & 7 & 8 & 9 & 10 & 11 & 12 & 13 & $\mathrm{Csv}$ & 14 & 15 & 16 & 17 & 18 & 19 & 20 & 21 & 22 & 23 & $\mathrm{Csv}$ & $\mathrm{Cv}$ & 24 & 25 & 26 & $\mathrm{Pv}$ & $\mathrm{Ct}$
\end{tabular}

Neottia nidus-avis

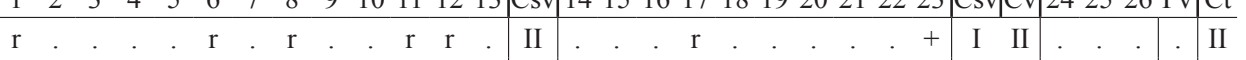

Oxalis acetosella

Pulmonaria obscura

Actaea spicata

Ajuga reptans

Dryopteris filix-mas

Eupatorium cannabinum

Gymnocarpium robertianum

Melampyrum sylvaticum

Paris quadrifolia

Sanicula europaea

Vaccinium myrtillus

Cotoneaster integerrimus

Knautia maxima

Poa stiriaca

Primula acaulis

Soldanella carpatica

Taraxacum sect. Ruderalia

Acer platanoides

Aegopodium podagraria

Cephalanthera damasonium

Cephalanthera longifolia

Galium odoratum

Laserpitium latifolium

Rubus idaeus

Pyrethrum clusii

Allium ochroleucum

Bellidiastrum michelii

Brachypodium sylvaticum

Bromus benekenii

Buphthalmum salicifolium

Cardaminopsis arenosa agg.

Carex flacca

Carlina acaulis

Cotoneaster tomentosus

Dentaria enneaphyllos

Galeobdolon montanum

Hordelymus europaeus

Lonicera xylosteum

Phyteuma spicatum

Padus avium

Rosa canina agg.

Rosa sp.

Teucrium chamaedrys

Tussilago farfara

Ulmus glabra

$\mathbf{E}_{\mathbf{0}}$

Bryum capillare

Dicranum scoparium

Hypnum cupressiforme

Tortella tortuosa

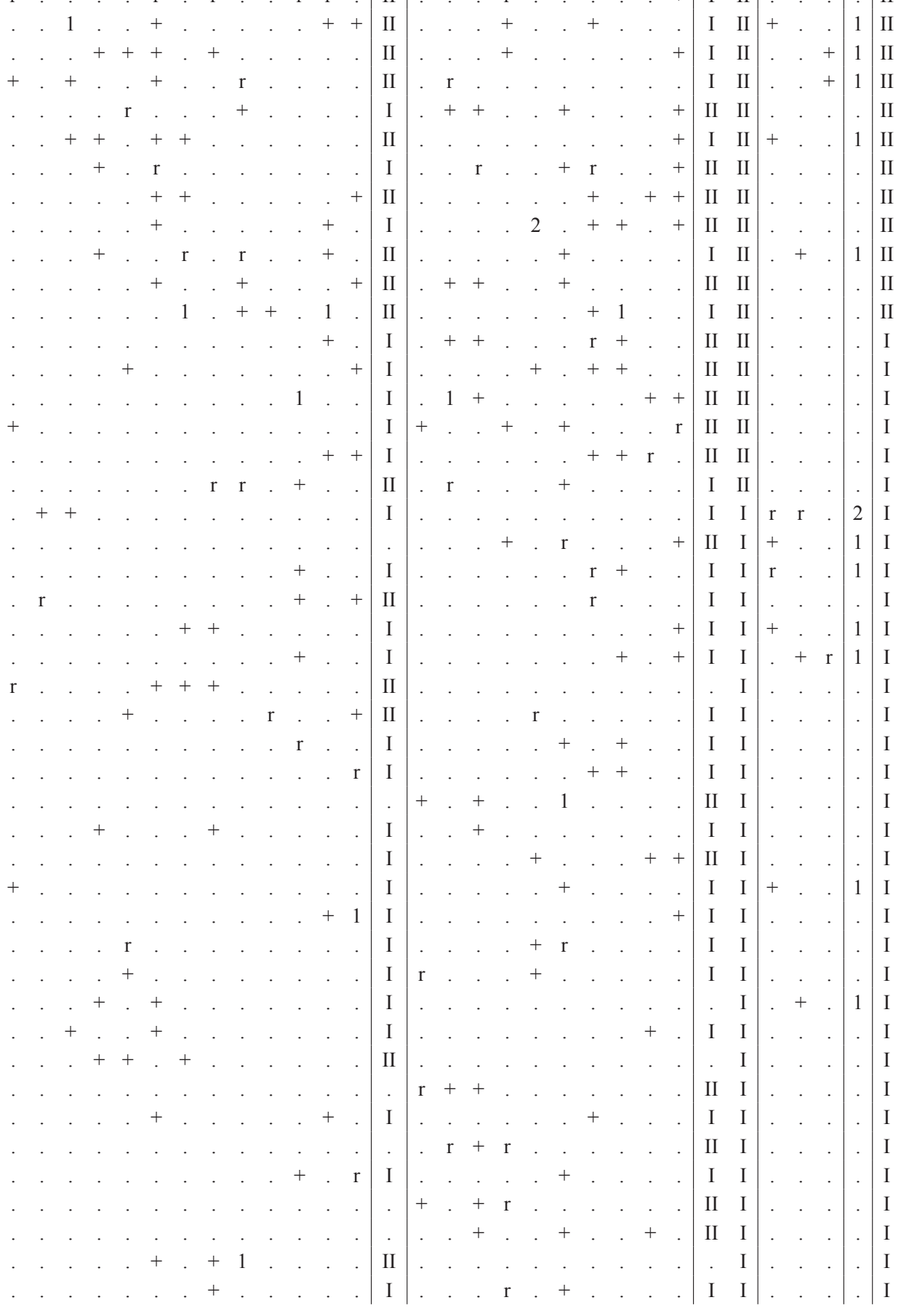

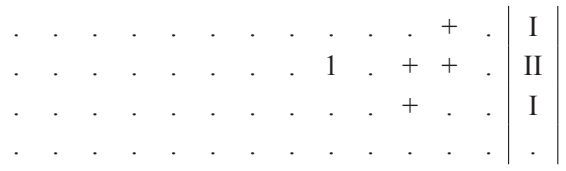

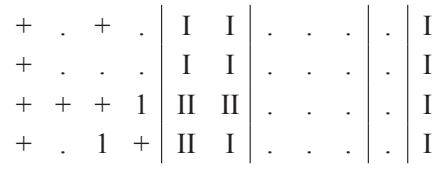


Species with occurrence in one or two relevés:

$\mathbf{E}_{3}$ : Acer platanoides 23: 2; Carpinus betulus 26: 1; Corylus avellana 14: 1; Fraxinus excelsior 4: 2; Pinus nigra 19: 1; Sorbus aucuparia 12: 1; Swida australis 26: 1; Salix caprea 4: 1; Tilia platyphyllos 22: 1; Ulmus glabra 4: 2, 26: 1; $\mathbf{E}_{2}:$ Abies alba 4: +, 5: 1; Corylus avellana 22: 1; Crataegus monogyna 14: 1; Rosa pendulina 22: +; Taxus baccata 3: +; Ulmus glabra 4: +; $\mathbf{E}_{1}$ : Acinos alpinus 18: +,22: +; Achilea distans 18: +,21: r; Aconitum vulparia 22: +; Anemone nemorosa 23: +; Arabis sagittata 7: +; Asperula tinctoria 23: +; Asplenium trichomanes 1: r; Asplenium viride 6: r, 20: +; Campanula cochlearifolia 20: +, 21: +; Campanula persicifolia 23: +; Cardamine impatiens 24: +; Carex diandra 12: +, 21: +; Carex montana 16: +; Clematis alpina 20: +, 23: +; Clinopodium vulgare 23: +; Cortusa matthioli 13: 1; Crataegus laevigata 16: +; Crataegus monogyna 19: r; Crepis biennis 19: r; Cyanus mollis 11:+, 23:r; Digitalis grandiflora 18: +; Epilobium montanum 24: r; Epipactis atrorubens 18: +; Epipactis microphylla 24: r; Euonymus europaeus 26: r; Frangula alnus 18: +, 19: 1; Galeobdolon luteum 9: +; Galeobdolon sp. 2: r; Galeopsis tetrahit 24: r; Galium anisophyllon 18: +, 21: +; Genista pilosa 19: r; Geranium robertianum 4: +; Goodyera repens 19: +; Hacquetia epipactis 3: +, 14: +; Hieracium lachenalii 10: +, 19: +; Hypericum perforatum 18: r; Jacea phrygia agg. 19: +; Knautia arvensis 19: +; Leontodon autumnalis 18: +; Leontodon hispidus 19: +; Leucanthemum margaritae 18: +; Ligustrum vulgare 16: +; Listera ovata 4: r; Lonicera nigra 17: +; Moneses uniflora 21: +; Petasites albus 13: +; Phyteuma orbiculare 22: +; Pimpinella saxifraga s.str. 19: +; Pinus sylvestris 16: r, 19: r; Pleurospermum austriacum 20: +, 21: +; Poa nemoralis 13: r; Polygala amara 18: +, 19: +; Polygonatum multiflorum 3: +; Polygonatum odoratum 19: +; Polystichum aculeatum 6: +; Potentilla heptaphylla 19: +; Primula elatior 5: r; Prunus spinosa 19: +; Pteridium aquilinum 16:+, 19:+; Pyrethrum corymbosum 14: +; Ranunculus lanuginosus 1: r; Ribes uva-crispa 24: +; Rubus fruticosus agg. 4: +; Scabiosa lucida 22: +; Secutigera varia 18: +, 19: +; Senecio germanicus subsp. germanicus 23: +; Senecio umbrosus 22: +, 23: +; Silene vulgaris 22: +; Spiraea media 16: +; Swida australis 16: +; Swida hungarica 17: +, 19: +; Swida sanguinea 22: +; Taraxacum sp. 23: +; Taxus baccata 3: +, 14: r; Thalictrum aquilegiifolium 1: +, 21: +; Tilia platyphyllos 22: +; Tofieldia calyculata 20: r; Urtica dioica 6: +; Vaccinium vitis-idaea 12: +, 21: +; Viburnum opulus 17: +, 19: $\mathrm{r} ; \mathbf{E}_{0}$ : Brachythecium salebrosum 22: 1; Brachythecium velutinum 22: +; Ctenidium molluscum 8: +, 20: +; Distichium inclinatum 21: +; Ditrichium flexicaule 19: +; Eurhynchium angustirete 19: +, 23: +; Fissidens dubius 12: +; Fissidens taxifolius 22: +; Hylocomium splendens 23: +; Lophocolea bidentata 23: +; Plagiochila porelloides 20: +, 23: +; Plagiomnium rostratum 23: +; Pleurozium schreberi 19: 2; Rhytidiadelphus triquetrus 20: +, 23: +; Scleropodium purum 23: +.

Table 2: Association Epilobio-Atropetum bella-donnae R. Tx. 1931 em. 1950, phytosociological table, P - presence. Tabela 2: Asociacija Epilobio-Atropetum bella-donnae R. Tx. 1931 em. 1950, fitocenološka tabela, P - prisotnost.

\begin{tabular}{|c|c|c|c|c|c|}
\hline \multicolumn{6}{|l|}{ Number of relevé } \\
\hline \multicolumn{6}{|l|}{$\mathbf{E}_{2}$} \\
\hline Fagus sylvatica & + & . & + & . & 2 \\
\hline Picea abies & . & 1 & 4 & . & 2 \\
\hline Rosa canina agg. & + & 1 & . & . & 2 \\
\hline \multicolumn{6}{|l|}{$\mathbf{E}_{1}$} \\
\hline Acer pseudoplatanus & 1 & 1 & + & 2 & 4 \\
\hline Astrantia major & 1 & + & + & + & 4 \\
\hline Calamagrostis varia & + & 2 & 1 & 5 & 4 \\
\hline Cirsium arvense & 1 & 1 & 1 & $\mathrm{r}$ & 4 \\
\hline Cyclamen fatrense & + & 1 & 1 & 1 & 4 \\
\hline Eupatorium cannabinum & 2 & 2 & 2 & 2 & 4 \\
\hline Fragaria vesca & + & + & 1 & + & 4 \\
\hline Galium schultesii & 1 & 1 & + & 2 & 4 \\
\hline Rubus idaeus & 2 & 1 & 1 & 1 & 4 \\
\hline Senecio ovatus & + & $\mathrm{r}$ & + & $\mathrm{r}$ & 4 \\
\hline Asarum europaeum & 2 & + & + & . & 3 \\
\hline Atropa bella-donna & + & + & + & . & 3 \\
\hline Brachypodium sylvaticum & 2 & + & + & . & 3 \\
\hline Campanula rapunculoides & + & + & . & 1 & 3 \\
\hline Carex alba & + & 1 & 2 & . & 3 \\
\hline Clinopodium vulgare & 2 & + & + & . & 3 \\
\hline Tithymalus_amygdaloides & + & + & + & . & 3 \\
\hline Mercurialis perennis & . & + & + & 1 & 3 \\
\hline Viola reichenbachiana & + & + & + & . & 3 \\
\hline Aegopodium podagraria & + & . & + & . & 2 \\
\hline Ajuga reptans & + & + & . & . & 2 \\
\hline
\end{tabular}

\begin{tabular}{|c|c|c|c|c|}
\hline Number of relevé & 1 & 2 & 3 & 4 \\
\hline Calamagrostis epigejos & 1 & . & 1 & . \\
\hline Campanula persicifolia & + & $\mathrm{r}$ & . & . \\
\hline Campanula trachelium & + & + & . & . \\
\hline Cirsium erisithales & . & + & . & + \\
\hline Swida hungarica & . & + & + & . \\
\hline Cruciata glabra & + & + & . & . \\
\hline Dryopteris filix-mas & + & . & + & . \\
\hline Epilobium montanum & + & + & . & . \\
\hline Tithymalus epithymoides & . & $\mathrm{r}$ & + & . \\
\hline Fagus sylvatica & . & . & + & 1 \\
\hline Hypericum hirsutum & + & . & + & . \\
\hline Maianthemum bifolium & . & + & + & . \\
\hline Mycelis muralis & + & . & . & + \\
\hline Picea abies & 1 & . & . & 2 \\
\hline Primula acaulis & + & + & . & . \\
\hline Rosa canina agg. & . & + & + & . \\
\hline Salix caprea & . & $\mathrm{r}$ & + & . \\
\hline Securigera varia & + & 1 & . & . \\
\hline Sorbus aria agg. & . & + & + & . \\
\hline Sorbus aucuparia & . & + & + & . \\
\hline Stachys sylvatica & + & + & . & . \\
\hline Urtica dioica & + & + & . & . \\
\hline Veronica chamaedrys & + & . & + & . \\
\hline Vicia cracca & + & . & + & . \\
\hline Vincetoxicum hirundinaria & . & + & $\mathrm{r}$ & . \\
\hline Viola riviniana & + & . & & + \\
\hline
\end{tabular}




\section{Headers of relevés presented in Table 1 and Table 2:}

Orographic unit; name and short description of locality; altitude (m a.s.l.); slope $\left(^{\circ}\right)$; exposition; abundance $\mathrm{E}_{3}(\%)$; abundance $\mathrm{E}_{2}(\%)$; abundance $\mathrm{E}_{1}(\%)$; abundance $\mathrm{E}_{0}(\%)$; relevé area $\left(\mathrm{m}^{2}\right)$; date; author/authors of the particular relevé.

Association Carici albae-Fagetum:

1. Velká Fatra Mts. (VF); village Rakša, dolina Mača valley, Drienok hill (1268 m); 970; 20; WSW; 95; 5; 10; 0; 400; 16.8.2001; Turis, Chilová.

2. VF; village Rakša, Rakšianska dolina valley, SE from elevation point Suché vrchy (664 m); 650; 25; SW; 95; 0; 10; 0; 400; 16.8.2001; Turis, Chilová.

3. VF; village Necpaly, Necpalská dolina valley, Priavna lateral small valley; 660; 30; NW; 90; 5; 10; 0; 400; 17.8.2001; Turis, Chilová.

4. Starohorské vrchy Mts. (SV); village Baláže, Krčahy hill (1129 m), J from elevation point; 970; 15; S; 85; 10; 30; 0; 400; 24.7.2001; Turis.

5. SV; village Baláže, Krčahy hill (1129 m), JZ from elevation point; 970; 30; SW; 75; 20; 35; 0; 400; 24.7.2001; Turis.

6. VF; village Liptovské Revúce, dolina Kutajova valley; 820; 30; SW; 90; 3; 15; 0; 400; 26.7.2001; Turis.

7. VF; Podšturec, dolina Chladná valley; $985 ; 25 ; \mathrm{W} ; 85 ; 3 ; 75 ; 0 ; 400 ; 26.7 .2001$; Turis.

8. VF; Podšturec, dolina Stará valley; 980; 20; S; 90; 20; 35; 1; 400; 26.7.2001; Turis.

9. VF; village Liptovské Revúce, dolina Kutajova valley, close to relevé nr. 14; 913; 20; NW; 90; 7; 40; 1; 400; 31.7.2002; Turis.

10. VF; Podšturec, dolina Stará valley, close to relevé nr. 16; 930; 40; SSE; 60; 10; 80; 0; 300; 31.7.2002; Turis.

11. VF; village Motyčky, Muráň; 835; 25; S; 80; 0; 70; 5; 375; 5.8.2002; Turis.

12. SV; village Motyčky, Bukovská dolina valley, Ťažalová lateral small valley; 885; 15; NW; 90; 0; 45; 2; 400; 5.8.2005; Turis.

13. SV; village Motyčky, Bukovská dolina valley, Poliakova lateral small valley; 800; 30; NNE; 90; 10; 70; 0; 400; 5.8.2002; Turis.

14. VF; village Rakša, dolina Mača valley, Jabloňská hill (751 m); 680; 45; S; 95; 5; 7; 0; 400; 16.8.2001; Turis, Chilová.

15. VF; village Necpaly, Necpalská dolina valley, Nosáková lateral small valley; 740; 45; NW; 70; 5; 80; 0; 400; 17.8.2001; Turis, Chilová.

16. VF; village Necpaly, Necpalská dolina valley, Nosáková lateral small valley, 300 m N from locality nr. 4; 700; 25; NW; 70; 10; 85; 0; 400; 17.8.2001; Turis, Chilová.

17. VF; village Belá, Belianska dolina valley, Šindolná lateral small valley; 660; 30; S; 80; 10; 25; 0; 400; 17.8.2001; Turis, Chilová.

18. VF; village Prášnica, NE from settlement; 860; 30; SW; 70; 1; 90; 0; 400; 26.7.2001; Turis.

19. VF; village Rakša, Rakšianska dolina valley, Suché vrchy hills (664 m); 600; 20; S; 40; 0; 98; 20; 400; 8.8.2002; Turis, Chilová

20. VF; village Valentová, dolina Rybô valley; 735; 40; NE; 75; $1 ; 70 ; 2 ; 400 ; 3.9 .2002$; Turis.

21. VF; village Horný Jelenec, Pohorenisko hill (932 m); 850; 20; E; 80; 10; 65; 2; 400; 3.9.2002; Turis.

22. VF; village Necpaly, Necpalská dolina valley, Morávková; 600; 35; SW; 70; 5; 60; 10; 100; 16.9.2002; Turis, Chilová.

23. VF; village Necpaly, Necpalská dolina valley, Baničná lateral small valley; 700; 30; SE; 70; 3; 85; 5; 400; 16.9.2002; Turis, Chilová.

24. SV; village Priechod, dolina L’upčica valley, Kopec hill (730 m); 470; 20; NE; 85; 2; 10; 0; 400; 20.7.2001; Turis.

25. SV; village Priechod, dolina Lupčica valley, Igovo; 530; 20; NE; 70; 5; 5; 0; 400; 23.7.2001; Turis.

26. SV; village Priechod, dolina Lupčica, Igovo, close to the locality nr. 9; 470; 30; N; 85; 15; 10; 0; 400; 23.7.2001; Turis.

\section{Association Epilobio-Atopetum belladonnae}

1. Velká Fatra Mts. (VF); village Rakša, Rakšianska dolina valley, WNW from the Havrania skala elevation point (924 m); 650; 15; NW; 0; 2; 100; 5; 100; 8.8.2002; Turis, Chilová.

2. VF; village Rakša, Rakšianska dolina valley, NE from elevation point Suché vrchy (664 m); 680; 15; N; 0; 5; 95; 0; 100; 8.8.2002; Turis, Chilová.

3. VF; village Necpaly, Necpalská dolina valley, Tokáreň hill; 650; 15; NE; 0; 70; 60; 2; 100; 16.9.2002; Turis, Chilová.

4. VF; village Motyčky, dolina Chladná valley, close to relevé nr. 15; 995; 20; WSW; 0; 0; 100; 0; 25; 31.7.2002, Turis. 